\title{
Producing Participants:
}

\section{Gender, Race, Class and Women, Peace and Security}

Recent efforts to implement the Women, Peace and Security (WPS) agenda and the creation of National Action Plans (NAPs) in post-conflict countries have resulted in a set of international policy discourses and practices on gender, peace and security. Critics have challenged the WPS agenda for its focus on "adding women and stir" and its failure to be transformative. This article contributes to this debate by showing that the implementation of the WPS agenda is not only about adding women, but also about gendering in racialized, sexualised and classed ways. Drawing on poststructuralist and postcolonial feminist theory and on extensive fieldwork in post-conflict contexts in DRC, Burundi and Liberia, the paper examines the subject-position of the woman participant. I demonstrate how NAPs normalize certain subject-positions in the global South while rendering invisible and troubling others, contributing to (re)produce certain forms of normativity and hierarchy through a powerful set of policy practices. Deconstructing such processes of discursive inclusion and exclusion of troubled representations is essential as it allows for the identification of sites of contestation and offers a better understanding of the everyday needs and experiences of those the WPS agenda regulates.

Keywords: Burundi, Liberia, DRC, gender, peacebuilding, post-structuralism

\section{Introduction}

Peacebuilding and post-conflict reconstruction efforts are perceived as key instances of major social and political transformation and consequently, as catalysts for integrating gender concerns. ${ }^{1}$ Decades of feminist advocacy directed to mainstreaming gender in post-conflict countries have resulted in a myriad projects and activities related to the implementation of UN Security Council Resolution (UNSCR) 1325, adopted in 2000, and subsequent resolutions conforming the Women, Peace and Security agenda (WPS). ${ }^{2}$

\footnotetext{
${ }^{1}$ Fionnuala Ni Aolain, Dina Francesca Haynes and Naomi Cahn, On the frontlines: gender, war, and postconflict process (Oxford and New York: Oxford University Press, 2011), p. 17; Stijn Smet, "A Window of Opportunity- Improving Gender Relations in Post-Conflict Societies: The Sierra Leonean Experience", Journal of Gender Studies, Vol. 18, No. 2 (2009), p. 147-63; Sheila Meintjes, Meredeth Turshen and Anu Pillay, The Aftermath: Women in Post-Conflict Transformation (London: Zed Books, 2001).

${ }^{2}$ The Women, Peace and Security agenda is composed by UN Security Council Resolutions 1325 (2000), 1820 (June 2008), 1888 (Sept. 2009), 1889 (Oct. 2009), 1960 (Dec. 2010), 2106 (June 2013), 2122 (Oct. 2013) and 2242 (Oct. 2015). For a history of WPS agenda, see Paul Kirby and Laura Shepherd, "Reintroducing women, peace and security", International Affairs, Vol. 92, No. 2 (2016), p. 249-54.
} 
UNSCR 1325 articulates three pillars (3Ps): the prevention of sexualised and genderbased violence; the protection of women against violence in conflict and post-conflict situations; and the participation of women in peace and security governance. The Global Study on the implementation of UNSCR1325 in October 2015 noted that since the adoption of the Resolution the percentage of women sitting at the negotiation table in peace agreements has doubled. However, it also indicated that only $9 \%$ of negotiators in 31 major peace processes between 1992 and 2011 were women and that only $3 \%$ of the military in UN missions are female staff. ${ }^{3}$ What is more, critical scholars argue that WPS policies on participation are about "adding women"4 and fail to be transformative. 5 They claim that WPS does not aim at structural change that provokes gender inequality in the first place and at promoting collective forms of development and emancipation, but rather at managing the existing situation of women in conflict zones. ${ }^{6}$ I suggest that the WPS amalgam of discourses and practices performed in postconflict states establishes a powerful rubric of intelligibility that determines how to make sense of, and implement, the agenda, who is a competent participant, which practices become acceptable and natural, and who should be in charge of putting them to work. $^{7}$

UNSCR1325 National Action Plans (NAPs) provide guidelines to governments and non-governmental actors on the responsibilities and activities to be carried out in a particular national or regional context in order to comply with the WPS agenda. ${ }^{8}$ Several studies investigating the implementation of NAPs in post-conflict states

\footnotetext{
${ }^{3}$ Radhika Coomaraswamy et al., Preventing Conflict, Transforming Peace, Securing the Peace: A Global Study on the Implementation of United Nations Security Council Resolution 1325 (New York: UN Women, 2015), p. 14.

${ }^{4}$ See Nadine Puechguirbal, "Discourses on Gender, Patriarchy and Resolution 1325: A textual analysis of UN documents", International Peacekeeping, Vol. 17, No. 2 (2010): 172-187; Sheri Gibbings, "No angry women at the United Nations: political dreams and the cultural politics of United Nations Security Council Resolution 1325", International Feminist Journal of Politics, Vol. 13, No. 4 (2011), p. 535; Jamie Hagen, "Queering women, peace and security", International Affairs, Vol. 92, No. 2 (2016), p. 313-332.

${ }^{5}$ Inger Skjelsbaek, The Political psychology of Rape: Bosnia and Herzegovina (London: Routledge, 2012); Aisling Swaine, "Assessing the potential of national action Plans to Advance implementation of United Nations Security Council Resolution 1325", Yearbook of International Humanitarian Law, Vol. 12 (2009) p. 403-433; Heidi Hudson, “A Double-Edged Sword of Peace?", International Peacekeeping, Vol. 19, No.4 (2012), p. 443-460.

${ }^{6}$ Soumita Basu and Joao Nunes, "Security as emancipation", in Laura Shepherd (ed.) Critical Approaches to Security: An Introduction to theories and methods, New York: Routledge, p. 63-76.

${ }^{7}$ Michel Foucault, The Order of Things (London/New York: Routledge, 2005); Laura Shepherd, "Power and Authority in the Production of United Nations Security Council Resolution 1325", International Studies Quarterly, Vol. 52, (2008), p. 383-404.

${ }^{8}$ Nicole George, "Institutionalising Women, Peace and Security in the Pacific Islands: Gendering the “architecture of entitlements?", International Political Science Review, Vol. 37, No. 3 (2016), p. 376-7.
} 
demonstrate how the Global North ascribes meaning on the Global South's policies on gender and security. ${ }^{9}$ These studies classify governments that have adopted NAPs into two groups: first, post-conflict countries that develop their NAPs to implement domestically with assistance from UN agencies and donor countries; second, developed countries that elaborate NAPs as part of their foreign policy, ${ }^{10}$ effectively making the WPS agenda mostly applicable to countries emerging from conflict. However, these studies do not offer an intersectional perspective, failing to provide a more nuanced account of relations of power on the ground, where several discourses, practices and NAPs compete with one another. Additionally, I argue that the WPS literature has overlooked the fact that the agenda is about gendering in racialized, sexualised and classed ways. ${ }^{11}$

The article draws on poststructuralist and postcolonial feminist literature ${ }^{12}$ that underlines the role of discourse in the production of subject positions and policy practices. ${ }^{13}$ I suggest that the concept of intersectionality is a useful tool in the analysis of gender subjectification processes and how these relate to other power relations (race, class, sexuality). As argued by Laura Shepherd, already in the title of the agenda, the word "women" indicates that WPS privileges gender above other power relations, such

\footnotetext{
${ }^{9}$ Sarai Aharoni, "Internal Variation in Norm Localization: Implementing Security Council resolution 1325 in Israel", Social Politics, Vol. 21, No. 1 (2014), p. 1-25; Annika Björkdahl and Joanna Mannergren Selimovic, "Translating UNSCR 1325 from the Global to the National: Protection, representation and participation in the National Action Plans of Bosnia-Herzegovina and Rwanda", Conflict, Security and Development, Vol. 15, No. 4 (2015), p. 311-335; Helen Basini and Caitlin Ryan, "National Action Plans as an obstacle to meaningful local ownership of UNSCR 1325 in Liberia and Sierra Leone", International Political Science Review, Vol. 37, No. 3 (2016), p. 390-403.

${ }^{10}$ Soumita Basu, "Gender as national interest at the UN Security Council", International Affairs, Vol. 92, No. 2 (2016), p. 266.

${ }^{11}$ Notable exceptions are Marjaana Jauhola, "Decolonizing branded peacebuilding: abjected women talk back to the Finish Women, Peace and Security agenda", International Affairs, Vol. 92, No. 2 (2016), p. 333-351; Nicola Pratt, "Reconceptualizing Gender, Reinscribing Racial-Sexual Boundaries in International Security: The Case of UN Security Council Resolution 1325 on "Women, Peace and Security", International Studies Quarterly, Vol. 57, No.4 (2013), p. 772-83.

${ }^{12}$ David Campbell, Writing Security: United States Foreign Policy and the Politics of Identity (Minneapolis: University of Minnesota Press, 1998); James Der Derian and Michael Shapiro, International/Intertextual: Postmodern Readings of World Politics (Lexington: Lexington Books, 1989); Lene Hansen, Security as Practice: Discourse Analysis and the Bosnian War (London and New York: Routledge, 2006); Laura Shepherd, Gender, violence and security: discourse as practice (London and New York: Zed, 2008); Jutta Weldes, Mark Laffey, Hugh Gusterson and Raymond Duvall, Cultures of Insecurity: States, Communities and Danger (Minneapolis: University of Minnesota Press, 1999). ${ }^{13}$ See Laura Shepherd, "Victims of violence or agents of change? Representations of women in UN peacebuilding discourse", Peacebuilding, Vol. 4 (2016), p. 121-135; Laura Shepherd, "Sex, security and superhero(in)es: From 1325 to 1820 and beyond", International Feminist Journal of Politics, Vol. 13 (2011), p. 504-521; Charlotte Epstein, "The postcolonial perspective: an introduction", International Theory, Vol. 6, No. 2 (2014), p. 294-311; Angela McRobbie, The aftermath of feminism: gender, culture and social change (Los Angeles and London: Sage Publications, 2009).
} 
as race, class or sexuality, and this privileging is necessary in order to (re) produce the two main subject positions of "women as victims of CRSV (conflict-related sexual violence)" and "women as peacebuilders and agents of change." 14 By focusing on the "women peacebuilders and agents of change", this article analyses the discursive construction of the competent and desirable "woman participant", as well as the possible, imaginable and permissible policies directed towards her (re)production through peacebuilding-related activities described by NAPs and associated projects on the ground. By doing so, the article reveals the productive power ${ }^{15}$ of the amalgam of WPS policy discourses and opens a window for further investigating the power relations involved in WPS practices. Finally, the article tries to account for the disjuncture between the subject positions of the woman participant envisioned by the WPS agenda and its NAPs, and the lived experiences and resistances of the woman participant herself.

The article offers a discourse analysis of two sets of discursive artefacts: key WPS implementation documents, produced by international organizations, national governments and non-governmental organizations, all of which are available online, ${ }^{16}$ and 40 semi-structured interviews in Burundi, Liberia and DRC. ${ }^{17}$ The interview data was generated during three periods of field research in Bujumbura, one period of research in Monrovia and one period of field research in DRC. Interviews were normally conducted individually and lasted around an hour each. The data analysed here is attributed anonymously, as promised to research participants. The choice of having two sets of discursive artefacts responds to the need to "provoke critical thinking... [and] challeng[e] unreflective protocols of official and institutionalized sense

\footnotetext{
${ }^{14}$ See Laura Shepherd, Victims of violence or agents of change?, op.cit.

${ }^{15}$ Michael Barnett and Raymond Duval, "Power in International Politics", International Organisation, Vol. 59, No. 1 (2005), p. 39-75.

${ }^{16}$ The set of documents were selected on the basis of their relevance to the issues analysed here. More particularly, the National Action Plans of Burundi, Liberia and DRC are the local implementation instruments of the WPS agenda, drafted to a large extent by a combination of government and civil society actors with the support and funding of UNWOMEN and international NGOs. Therefore, it is useful to interrogate their content and to investigate which subject positions they assign to women and which type of knowledge about gender sensitive peacebuilding is represented. I coded the sections and objectives related to "participation" of women in peace and security governance by using the software NViVo10. The rest of documents serve as complements to understand the meanings and implementation strategies of the NAPs.

${ }^{17}$ For similar methodological approaches see: Laura Shepherd, Victims of violence or agents of change?, op. cit.; Kathleen Jennings and Morten Bøås, "Transactions and Interactions: Everyday Life in the Peacekeeping Economy", Journal of Intervention and Statebuilding, Vol. 9, No. 3 (2015), p. 281-295.
} 
making". ${ }^{18}$ The first section of the article constitutes a literature review and presents the theoretical framework. The second section examines the construction of the woman participant in policy documents. The third section provides a critical reading that identifies the sexualised, classed and racialized essentializations of WPS policy practices in post-conflict contexts and its resistances proposed by the research participants in the semi-structured interviews.

\section{Critical approaches to the Women, Peace and Security agenda}

There is a general consensus in the literature on the Women, Peace and Security agenda that suggests that existing policy initiatives for its implementation are good on paper but do not change the current state of affairs. ${ }^{19}$ The agenda is rather considered an instrument of a liberal approach to international peace and security and its imperial construction of a series of dichotomous discourses that differentiate between developed and underdeveloped, modern and traditional, local and global, man and woman, black and white, liberal and illiberal against each other. ${ }^{20}$ Postcolonial feminist claim that these differentiations evoke certain continuities with the colonial era. ${ }^{21}$ For example, although the agenda gives a voice to "third world women" in conflict, these women are heard by the UN because they supposedly "embody the universal principles of peace and security as opposed to the local (tribal or ethnic) interests of particular communities". 22

\footnotetext{
${ }^{18}$ Michael Shapiro, War crimes, atrocity, and justice (Cambridge: Polity, 2015), p. 1, cited in Jauhola, op. cit., p. 336.

${ }^{19}$ Susan Willett, "Introduction: Security Council Resolution 1325: assessing the impact on Women, Peace and Security", International Peacekeeping, Vol. 17, No. 2 (2010), p. 142-58; Christine Bell and Catherine O'Rourke, "Peace agreements or pieces of paper? The impact of UNSC Resolution 1325 on peace processes and their agreements", International and Comparative Law Quarterly, Vol. 59, No. 4, (2010), p. 941-80.

${ }^{20}$ Heidi Hudson, "Decolonizing the mainstreaming of gender in peacebuilding: Towards an agenda for Africa", African Peacebuilding Network Working Papers, No. 8 (2016).

${ }^{21}$ Gayatri Spivak describes colonial relations in terms of "white men saving brown women from brown men" and denounces the hierarchies of race, gender and sexuality that govern the Western imperial politics over the rest in "Can the Subaltern Speak?", in Cary Nelson and Lawrence Grossberg (eds.), Marxism and the Interpretation of Culture (London: Macmillan, 1988), p. 92.

${ }^{22}$ Gibbings, op. cit., 529-531.
} 
For many, WPS mirrors the discourses and practices of the "neoliberal imperium", ${ }^{23}$ the "war on terror" 24 and the countering violent extremism strategies. ${ }^{25}$ These authors claim that although the WPS agenda does indeed represent women not only as passive victims of conflict, but also as agents of change, ${ }^{26}$ it does so by reinforcing racial, sexual and gendered discourses and practices of international peace and security to produce "governance feminism." 27 In other words, they argue that local feminist knowledge and goals are adapted and co-opted by governmental agendas as "gender is turned into a technocratic tool and stripped of its critical content". ${ }^{28}$ For example, when implementing the agenda, national and international authorities have concentrated on protecting women from conflict-related sexual violence (CRSV), instead of focusing efforts on avoiding violence and war altogether. ${ }^{29}$ Other scholars also argue that governments have directed their attention towards violence prevention and protection issues, leaving behind other goals, such as women's participation in peace and security governance. ${ }^{30}$ What is more, when women's participation is addressed, ${ }^{31}$ policy proposals are summed up by putting more women in governance positions, without telling anything about "where female peacekeepers are sent, or what kind of activities is entrusted to them." 32

\section{Intersecting productive power, subject positions and subjectivities}

\footnotetext{
${ }^{23}$ Anna Agathangelou and Lily Ling, Transforming World Politics: From Empire to Multiple Worlds (London and New York: Routledge, 2009), p. 2-3.

${ }^{24}$ Pratt, op.cit., p. 773.

25 Fionnuala Ni Aolain, "The 'war on terror' and extremism: assessing the relevance of WPS", International Affairs, Vol. 93, No. 2 (2016), p. 275-291.

${ }^{26}$ See Carol Cohn, Helen Kinsella and Sheri Gibbings, "Women, Peace and Security, Resolution 1325", International Feminist Journal of Politics, Vol. 6, No. 1 (2004), p. 130-140.

27 Janet Halley, Split Decisions: How and Why to Take a Break from Feminism (Princeton, NJ: Princeton University Press, 2006), p. 20-22.

${ }^{28}$ Audrey Reeves, "Feminist knowledge and emerging governmentality in UN peacekeeping", International Feminist Journal of Politics, Vol. 14, No. 3 (2012), p. 349.

${ }^{29}$ Laura Shepherd, "Making war safe for women? National Action Plans and the militarisation of the Women, Peace and Security agenda", International Political Science Review, Vol. 37, No. 3 (2016), p. 324-335.

${ }^{30}$ Caroline Moser and Fiona Clark, "Introduction", in Caroline Moser and Fiona Clark (eds), Victims, Perpetrators or Actors? Gender, Armed Conflict and Political Violence (London: Zed, 2001).

${ }^{31}$ For a critical approach of the UN politics of representing women as peacebuilders and agents of change, see Hilary Charlesworth, "Are Women Peaceful? Reflections on the Role of Women in Peacebuilding", Feminist Legal Studies, Vol. 16, pp. 347-61; Sanam Anderlini, Women Building Peace: What they do, why it matters (Boulder, CO: Lynne Rienner, 2007); Laura Shepherd, "Sex, Security and Superhero(in)es", op. cit.

32 Paul Kirby and Laura Shepherd, "The futures past of the Women, Peace and Security agenda", International Affairs, Vol. 92, No. 2 (2016), p. 375.
} 
Rather than evaluating the effectiveness of WPS agenda policy initiatives or its instrumentalization, the aim of this article is to demonstrate how NAPs function to frame the woman participant as a target of intervention and fabrication, rather than as the agent of societal transformation. It therefore shifts the focus towards the productive power of the WPS agenda in (re) producing certain forms of (gendered and heterosexual) normativity and (racialized and classed) hierarchy in local post-conflict contexts. Barnett and Duvall define productive power as "the constitution of all social subjects with various social powers through systems of knowledge and discursive practices of broad and general social scope." ${ }^{33}$ First, productive power is exerted through language and discourse, as it is behind "the processes and systems of knowledge through which meaning is produced, fixed, lived, experienced, and transformed." 34 Second, it produces social identities by "constituting the subjectivity of all social beings of diverse kinds with the contingent, though not entirely fluid, identities, practices, rights, responsibilities, and social capacities. ${ }^{35}$ That is, analysing productive power is to focus on the construction of the subject, of the "Other", and on the policies and practices that "are [deemed] possible, imaginable, permissible, and desirable" in this construction. ${ }^{36}$

However, are individuals only bearers of these gendered and racialized social identities? How do they respond to them? The differentiation between subjectivity and subjectposition can prove useful to answer these questions. Subject-positions are the product of discourses,${ }^{37}$ and their elaboration is an ongoing process that depends on practices and distribution of power. ${ }^{38}$ Subject positions, therefore, constrain what can be thought, said and done. ${ }^{39}$ They are not only socially constructed, but they are also the outcome of a power that is most successful when agency appears to be strong. Much to the contrary, subjectivity refers to a person's sense of self, to her political agency, and cannot be

\footnotetext{
${ }^{33}$ Barnett and Duvall, op. cit., p. 55.

${ }^{34}$ Ibidem

35 Judith Butler, Gender Trouble: Feminism and the Subversion of Identity (New York: Routledge, 1999).

${ }^{36}$ Barnett and Duvall, op. cit., p. 57; Campbell, op. cit.; Iver Neumann and Jennifer Welsh, "The Other in European Self-Definition: An Addendum to the Literature on International Society", Review of International Studies, Vol. 17, No. 4 (1991), p. 327-48.

${ }^{37}$ Charlotte Epstein, "Who speaks? Discourse, the subject and the study of identity in international politics", European Journal of International Relations, Vol. 17, No. 2 (2011), p. 327-350.

${ }^{38}$ Bronwyn Davies and Rom Harré, "Positioning: The discursive production of selves", Journal for the theory of social behaviour, Vol. 20, No. 1 (1990), p. 43-63.

${ }^{39}$ Margaret Wetherell and Jane Maybin, "The distributed self: A social constructionist perspective", in Richard Stevens (ed.), Understanding the self (London: Sage and Open University Press, 1996).
} 
reduced to being discursive phenomenon. ${ }^{40}$ Subjectivities are particular ways of being in the world, or acts of identification that "acquire a temporarily privileged status within a specific discourse". ${ }^{41}$ Therefore, they are individual, unstable and malleable, and only temporarily fixed..$^{42}$ As a site of struggle, they are performed by the speaking subject, who may accept or try to reject the subject positioning s/he has been assigned, sometimes through active discursive resistance.

Wetherell uses the term "troubled subject position" to identify verbal practices, interactions and negotiations where subject positions and subjectivities become inappropriate, destabilized and challenged. ${ }^{43}$ When taking intersectionality seriously, not only does it become evident that there are positions more "troublesome" than others, but also that there are positions more "invisible" than others, depending on a particular distribution of power and hegemony around certain social categories. Gender, race, sexuality and class are some of the classical social categories around which meaning is clustered. They work to select, order, include and exclude. Inspired by Foucault's analysis of how power and knowledge are 'joined together' in discourse, the next sections of the article contribute to the postcolonial literature that analyses how Western discourses have constructed the postcolonial world as a governable object. I do this by analysing the exclusionary ways in which the WPS agenda creates, naturalizes and gives legitimacy to certain representations of the subject position of the "woman participant", while troubling or silencing others. These representations do not only construct the "I/We" versus the "Other", but also the appropriate and inappropriate, the competent and incompetent "Other", fabricating and regulating otherness at local, national and international levels.

\section{Producing the Subject-Position(s) of the "woman participant"}

The priorities of the WPS agenda have changed throughout the years. Nevertheless, the participation pillar, in which the UN Security Council recognizes "the importance of the full and effective participation of women at all levels, at all stages and in all aspects of

\footnotetext{
40 Epstein, "Who speaks?", op.cit.

${ }^{41}$ Bucher, Bernd and Ursula Jasper, "Revisiting 'identity' in International Relations: From identity as substance to identifications in action", European Journal of International Relations, Vol. 23, No. 2 (2017), p. 393.

${ }^{42}$ Chris Weedon, Feminist Practice and Poststructuralist Theory (Oxford: Blackwell Publishing, 1997).

${ }^{43}$ Margaret Wetherell, "Positioning and interpretative repertoires: conversations analysis and poststructuralism in dialogue”, Discourse and Society, Vol. 9, No. 3 (1998), p. 387-412.
} 
the peaceful settlement of disputes, conflict prevention and resolution, as well as the provision of adequate gender expertise for all mediators and their teams..." 44 has been considered the transformative one. Indeed, evidence points out that WPS agenda has been used as a strategic tool by women activists in conflict zones, by giving them voice before officials and policy-makers. ${ }^{45}$ In Burundi the agenda was very popular amongst local women organisations that, together with some international NGOs, used it as an advocacy tool to mainstream the general elections in 2005 and 2010 through a campaign titled "Yes, she also can". Furthermore, in 2007 the international NGO Femmes Africa Solidarité funded the creation of a steering committee with members from civil society organisations (CSOs) and government in charge of drafting the Burundian National Action Plan (BNAP) on the implementation of UNSCR1325 in the country, which was finally adopted in December 2011.

The Liberian National Action Plan (LNAP) also promotes the role of women organisations. It includes measures such as developing a roster of competent women in peace-building and conflict prevention and it contains a list of women and communitybased organisations that can participate in post-conflict reconstruction activities. The Plan was also drafted by women organisations and government staff in 2009 in what has been described as an inclusive process involving a governmental commission, a parliamentary committee and CSOs. The same structure and inclusive approach was used in the drafting of the 2010 Democratic Republic of Congo NAP (CNAP). Furthermore, a national steering committee, in which 10 out of 40 members represent CSOs, monitors the implementation of the 2010 CNAP, revised in $2013 .{ }^{46}$

More recently, the Global study undertook by UNWOMEN in 2015 identified that " $88 \%$ of all peace processes with UN engagement in 2014 included regular

\footnotetext{
${ }^{44}$ Security Council, UNSCR1325 on Women, Peace and Security, 2000.

${ }^{45}$ Amy Barrow, "[It's] like a rubber band." Assessing UNSCR 1325 as a Gender Mainstreaming Process", International Journal of Law in Context, Vol. 5, No. 1 (2009), p. 51-68; Vanessa Farr, "UNSCR 1325 and Women's Peace Activism in the Occupied Palestinian Territory", International Feminist Journal of Politics, Vol. 13, No. 4 (2011), p. 539-556; Laura McLeod, "Configurations of Post-Conflict: Impacts of Representations of Conflict and Post-conflict upon the political translations of Gender Security within UNSCR 1325", International Feminist Journal of Politics, Vol. 13, No. 4 (2011), p. 594-611; Margret Owen, "Widowhood Issues in the Context of UNSCR 1325", International Feminist Journal of Politics, Vol. 13, No. 4 (2011), p. 616-622.

${ }^{46}$ Global Network of Women Peacebuilders, Women Count: Security Council Resolution 1325 -Civil Society Monitoring Report 2014, p. 12.
} 
consultations with women's organizations, a notable rise from 50\% in 2011." ${ }^{\prime 4}$ However, the same report admits that these consultations are sometimes just procedural and there is no conscious preparation, representativeness and follow-up. ${ }^{48}$ This was also a remark made by the president of a local women's NGO from Monrovia, Liberia:

"I'm disappointed because I realized that the people who need the services and whose lives should be transformed, have not been transformed. People come and interview the persons that have the information and when they come back to do the implementation with the information that they gather, they don't work with the people... [...] It is rather getting to the stage where I tell the people: "look, I'm not going to give an interview anymore". 49

The logic here is that participation of local women's groups meets the desire of donors to obtain the civil society "stamp of approval" 50 for women's participation. The knowledge acquired through local women is necessary to implement and create a suitable NAP, but it is then the international community, who knows better how to transform that information into sustainable practices for women involvement in peace and security governance. ${ }^{51}$ Consequently, throughout the subject-position of the woman participant in post-conflict countries, attention is directed towards the woman victim who needs to be empowered to become a woman participant, and away from those who produced this woman as a governable individual. Indeed, in some countries, NAPs are considered as irrelevant, as '[this] is not a country in conflict'. ${ }^{52}$ What is more, in some Western countries, the NAPs are a combination of domestic objectives and foreign policy ones. For example, the Netherlands NAP focuses as well on women's political

\footnotetext{
${ }^{47}$ Radhika Coomaraswamy et al., Preventing Conflict, Transforming Peace, Securing the Peace: A Global Study on the Implementation of United Nations Security Council Resolution 1325 (New York: UN Women, 2015), p. 45.

48 Ibidem

${ }^{49}$ Interview with a President of a women's organisation in Monrovia, Liberia, (10 September 2013).

${ }^{50}$ For an account on the understandings of the figure of the woman-in-conflict and the woman activist, see Sam Cook, "The 'woman-in-conflict' at the UN Security Council: a subject of practice", International Affairs, Vol. 92, No. 2 (2016), p. 353-372.

${ }^{51} \mathrm{At}$ this point, one also wonders about the role of the researcher in producing the subject-position of the woman participant as a source of information from whom to "extract" data that is then analysed and interpreted through Western perspectives. For an argument on the need to be overtly conscious about our own place and even our own complicity as knowers and developers of subject-positions, see: Maria Martin de Almagro, "Politicized Discourses. A Reflexive Approach to the Transnational Campaign on Women, Peace and Security and its Local Narratives", Anthropologie \& développement, Vol. 44 (2016), p. 101-122.

${ }^{52}$ Marjaana Jauhola, op.cit, p. 336.
} 
participation and female leadership in Burundi and $\mathrm{DRC}^{53}$ and the UK NAP has selected 6 focus countries where "through local consultations in-country, we have determined there is a local appetite for change". ${ }^{4}$ Talking about the DRC, the UK NAP states that "violence against girls is strongly linked to gender inequalities and sociocultural norms. It manifests as the disempowerment of women as social, political and economic actors. It is also linked to strong ideas about masculinity, the breakdown of traditional structures and militarization of society". ${ }^{55}$ The juxtaposition of violence and inequalities with "socio-cultural norms" links the difficulties of women participation with the "barbaric masculinities" and militarized patriarchy of the "brown men" in conflict areas. ${ }^{56}$ This fact is symptomatic of the binary construction of "us" versus "them" that racializes the WPS and constructs an international community divided between those countries whose NAPs only contain domestic targets - the colonial, the traditional Other - and those countries who, forgetting or minimising inequalities at home transform something as domestic as a "National" Action Plan into an instrument of foreign policy - the modern, civilized Us. ${ }^{57}$

Moreover, the funding for implementation of the NAPs enables the construction of new alliances between local women's groups and social movements on the one hand, and UN agencies, donors, and international NGOs on the other in post-conflict situations. ${ }^{58}$ This makes us question whether the WPS agenda is a tool for women in conflict zones to access spaces not accessible to them before or rather whether the agenda enables the Security Council and Western donors to instrumentalize women participants in postconflict and reconstruction spaces for the objectives of an international agenda on peace and security. ${ }^{59}$ The following section suggests that the development of the figure of the woman participant in conflict settings throughout NAPs have made these women much more visible in ways that have facilitated their creation as new subjects of international intervention. At the same time, these new subjects become self-disciplining. That is,

\footnotetext{
${ }^{53}$ The Netherlands National Action Plan on Women, Peace and Security

${ }^{54}$ United Kingdom National Action Plan on Women, Peace and Security

55 Idem, p. 20.

${ }^{56}$ Nicola Pratt, op.cit, p. 775.

${ }^{57}$ Shepherd, "Making war safe for women?", op.cit.

${ }^{58}$ Anne-Marie Goetz and Shireen Hassim, No shortcuts to power: African women in politics and policy making, Vol. 3 (London: Zed Books, 2003).

${ }^{59}$ Cohn, Kinsella and Gibbings, 2004, op.cit. ; Carol Cohn, "Mainstreaming Gender in UN Security Policy: A Path to Political Transformation?", in Shirin Rai and Georgina Waylen (eds.), Analysing and

Transforming Global Governance: Feminist Perspectives (Cambridge: Cambridge University Press, 2008).
} 
these women "know themselves" through dominant ideas about what it means to be a competent participant and they have disciplined themselves to act and feel accordingly.

\section{The Competent, the Troublesome and the Invisible Woman Participant}

In this section, I analyse the documents gathered from the digital archive of the UN, specifically the Global Study on the Implementation of UNSCR 1325, the BNAP, the CNAP, the LNAP, the regional action plan for the Great Lakes in Africa, the African Union Commission report on and related NGO reports on the implementation of the Agenda. I then contrast it with women's stories obtained through semi-structured interviews. Additionally, as it is rather difficult to access female interviewees in the security forces since they represent a rather low number, the primary sources for this category have been found through secondary literature, on interviews in a documentary on DRC female soldiers and on a Dutch radio programme that analyse the woman's place in the African army. ${ }^{60}$

Exploring the production of the "woman participant" is not intended to claim that there is some universal "woman" and some essential "participant" out there in post-conflict contexts and whose subject-position, together with any specificity of race, class and sexuality, can be clearly identified. For the purpose of this article, a number of entry points have been labelled. They fall into three broad categories: the woman soldier, the woman mediator and the woman activist. This section demonstrates how when studied in an intersectional manner - looking at gender and sexuality, gender and race and gender and social class, respectively - it becomes evident that there is a competent, a troublesome and an invisible woman participant. What is more, in the three cases, women need to be empowered and trained by the international community so that they can become competent soldiers, mediators and activists. $\mathrm{T}$ The woman participant is constituted according to the discourse of the ones who empower and who have the resources for discourse (re)production through training and financial aid. This fosters

\footnotetext{
${ }^{60}$ Stéphanie Lammorré, Mathieu Goasguen and Bruno Tabaskko, Combattantes du Nord Kivu. L'impossible destin. Arte, (21 August 2015), available: $<$ https://www.youtube.com/watch?v=DI6xMzy hLk>(accessed 15 November 2016) ; Radio interview, "La Place de la Femme dans l'armée en Afrique ", (29 November 2011), available: <www.rnw.nl/afrique/radioshow/la-place-de-la-femme-dans-1\%E2\%80\%99arm\%C3\%A9e-en-afrique> [accessed 18 November 2015]; Irma Specht, Experiences of girl-combatants in Liberia, ILO Program on Crisis Response and Recontruction, undated, available: $<$ http://www.ilo.org/wcmsp5/groups/public/--ed emp/---emp ent/---ifp crisis/documents/publication/wcms 116435.pdf > (accessed 18 November 2016)
} 
relations of power, ${ }^{61}$ reinforcing and normalising social hierarchies reminiscent of the colonial period, with local upper-middle class educated elites working as intermediaries (see figure 1). This effectively constrains women participants in a racialized, sexualised and classed subject position that suppress particularities and produce unintended consequences. ${ }^{62}$

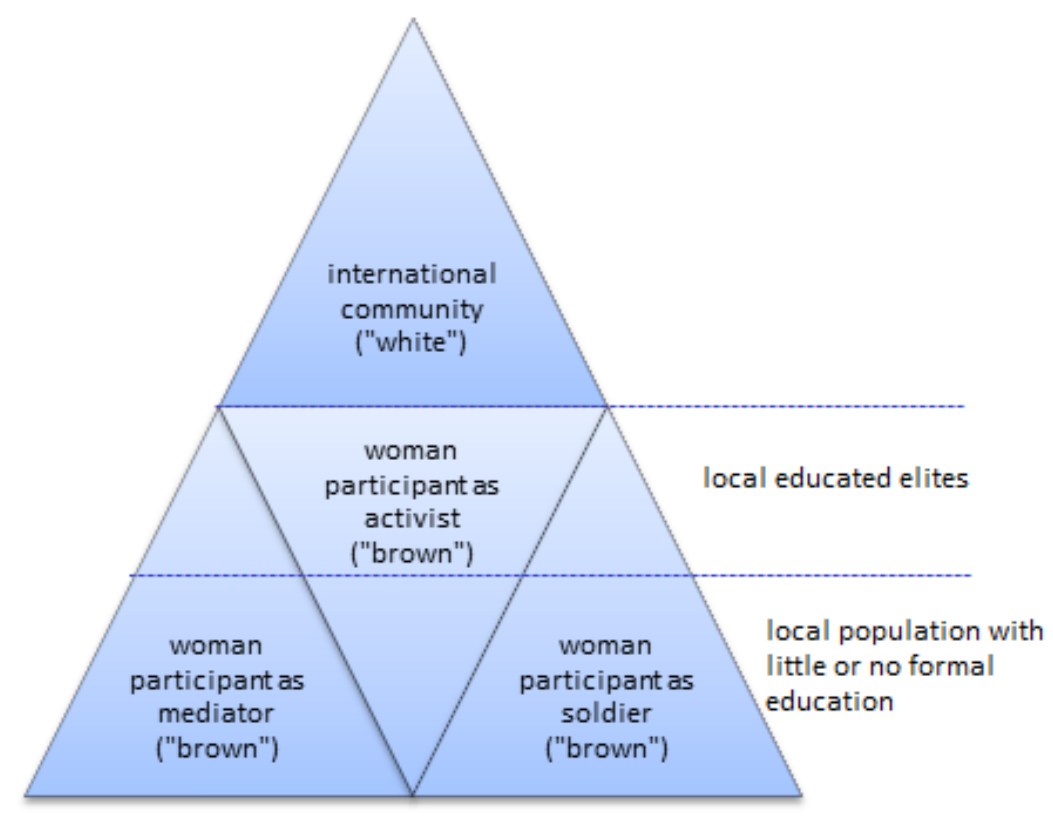

Figure 1: Pyramid of social hierarchies after implementation of the WPS agenda

The objective is then to understand the subject position of "woman participant" as it appears and is produced in the WPS agenda and its articulatory practices. ${ }^{63}$ The second objective is to examine how the "woman participant" herself contests normalisation and tries to (un) fix the meaning of the subject position. As it would be materially impossible to study every contestation, the examples I use in the following sub-sections are considered as moments of representation enacted in practice.

\section{The woman soldier or the intersection of gender and sexuality}

\footnotetext{
${ }^{61}$ A Cornwall, "Whose voices? Whose choices? Reflections on Gender and Participatory Development", World Development, Vol. 31, No. 8 (2003): 1325-1342.

62 Marysia Zalewski, "I don't even know what gender is": A discussion of the connections between gender, gender mainstreaming and feminist theory", Review of International Studies, Vol. 36, No. 1 (2010); Marjaana Jauhola, op.cit. ; Olivera Simic, Regulation of Sexual Conduct in UN Peacekeeping Operations (Berlin/Heidelberg: Springer, 2012).

${ }^{63}$ Ernesto Laclau and Chantal Mouffe, Hegemony and socialist strategy: towards a radical democratic politics (London and New York: Verso, 1985), p. 113.
} 
This first subject position will be analysed by intersecting gender and sexuality through the figure of the woman soldier. The logic of the WPSA in this respect is to include more women into highly masculinized spheres such as the military and high instances of decision making on peace and security, spheres where women traditionally used to be passive victims in need of protection. Similarly to what other observers had already found, ${ }^{64}$ rather than being a form of gender mainstreaming, the inclusion of quotas for women in security forces or in government in the Liberian, Burundian and DRC NAPs looks much more as a way to deal with problems of gender violence, sexual exploitation and abuse. For example, the BNAP's objective 3 is to "put in place mechanisms against SGBV and a transitional justice system that integrates gender concerns" through "the creation of a workshop and sensitising activities directed to recruit girls in security and defence forces." Recruiting girls so that they participate in security forces is then one of the solutions proposed against sexual violence. As heteronormativity is assumed, a masculine domination in security forces is seen as the cause of violence and abuse towards the populations in need of protection. ${ }^{65}$ Furthermore, while this subject-position can potentially destabilize the hierarchical binary of the men as protectors and women as victims, there is a risk of essentializing women's capacities and skills as women being different security providers, with nurturing and caring skills, due to their sex role. For instance, in DRC, the police force now aims at 30\% of women's participation (estimated at $6 \%$ in 2010) (66 $^{6}$ and is working at gender mainstreaming in nomination, recruitment and promotion processes. The aim of the reform is to increase trust in the police and adapt to a "community policing" approach. ${ }^{67}$ However, this strategy might not work in some contexts, as the assumptions made about women's essential nature and their suitability for nurturing and caring might not be reproduced and appropriated by female security forces.

\footnotetext{
${ }^{64}$ Tarja Vayrynen, "Gender and UN Peace Operations: The Confines of Modernity", International Peacekeeping, Vol. 11, No. 1 (2004): 125-142; Sandra Whitworth, Men, Militarism and UN Peacekeeping: A Gendered Analysis (Boulder: Lynne Rienner, 2004); Kathleen Jennings, Women's Participation in UN Peacekeeping Operations: Agents of Change or Stranded Symbols? (Oslo: Norwegian Peacebuilding Resource Centre, 2011).

${ }^{65}$ Sandra Whitworth, Men, Militarism and UN Peacekeeping: A Gendered Analysis (Boulder: Lynne Rienner, 2004).

${ }^{66}$ Congolese National Action Plan, 2013, p. 24.

${ }^{67}$ Amling and O'Reilly, op.cit., p.16.
} 
This brings us to the troublesome and the invisible female soldier and ex-combatant. One of the activities proposed by the BNAP in this regard is the "creation and implementation of gender-sensitive reintegration programs for refugees, internally displaced people and ex-combatants". The UN and the national government in collaboration with CSOs are in charge of setting up these programs. The problem is that simultaneously-led UN exercises, such as its Disarmament, Demobilisation and Reintegration program (DDR), do not comply with, and in several instances prevent, the implementation of the principles and activities contained in the NAPs. For instance, to qualify as a combatant in Burundi for the purposes of participating in the DDR programme, one had to, among others, 'surrender a set quota of weapons and ammunition' and 'be able to demonstrate knowledge of basic military training' ${ }^{68}$ The majority of female candidates were not eligible to participate, as armed groups in Burundi functioned under heteronormative assumptions where women are not allowed to carry weapons, but are rather dedicated to "women's" tasks such as cooking and cleaning, or are used as wives and sexual slaves. They have been invisible to the "one combatant-one gun" eligibility programs of UN Disarmament, Demobilisation and Reintegration processes (2004-2011) and the demobilisation package, even though the $\mathrm{UN}$ is also responsible for implementing the gender-sensitive reintegration program for ex-combatants. ${ }^{69}$ Not only do they become invisible participants, but they are identified by international community programs as victims of sexual and gender based violence, and trapped in a mutually exclusive dichotomy of victim-perpetrator that strips them from agency. ${ }^{70}$ This only let us see how women suffered violence, but not how they contributed to it or sought to empower themselves in a war environment.

In DRC the army counted with a good amount of women that the State calls "Female Military Personnel (FMP)". ${ }^{71}$ When the National Program for Disarmament, Demobilization, and Reintegration (PNDDR) was established in 2005, women part of the FMP were asked to opt in, but some of them are tired and would prefer not to,

\footnotetext{
68 Albert Caramés, "Burundi (PNDDR, 2004-2008)", in Albert Caramés and Eneko Sanz (eds.), DDR 2009. Analysis of Disarmament, Demobilization and Reintegration (DDR) Programmes in the World during 2008 (School for a Culture of Peace: Bellaterra, 2009), p. 31-38.

${ }^{69}$ Mark Knight and Alpaslan Özerdem, "Guns, Camps and Cash: Disarmament, Demobilization and Reinsertion of Former Combatants in Transitions from War to Peace", Journal of Peace Research, Vol. 41, No. 4 (2004), p. 500.

${ }^{70}$ Nina Wilen, "SSR, gender and local narrative in Burundi", Conflict, Security and Development, Vol. 14, No. 3 (2014), p. 331-354

71 « Combattantes au Nord Kivu », op. cit.
} 
troubling and preventing the national army and its international partners from benefiting from "feminine soft skills": "I have spent years in the bush. I got nothing out of it. Now they ask us to integrate the army, but I don't want to go back to the bush". ${ }^{72}$ This quote resonates with MacKenzie's findings in Sierra Leone, ${ }^{73}$ where, she argues, female excombatants did not participate in DDR because they did not trust the government, the international community and the NGOs organising the process. Other women who were left out of demobilisation programs and were rejected or abandoned by their family in DRC, had to relocate to different communities because of fear of stigma: "I "I cannot even return to Nyanzale, my native village. They know that I have been part of a militia group. They will stone me." 75 All of these women destabilize the women as victim or the women as participant narrative established within the WPS normativity and could be a latent pocket for resistance and contestation, as demonstrated by the empirical material here proposed.

\section{Women as mediators or the intersection between gender and race}

The role of women as mediators and negotiators is translated by the BNAP as objective 8: “To guarantee equality and equity of women's and men's participation in negotiation processes and in diplomatic positions". In order to achieve this objective, the BNAP proposes several activities, such as the building of a database of women who could be eligible to national and international positions in peace and security governance and also in diplomatic missions, as well asthe organisation of a series of workshops for capacity building for women who could be eligible to positions in negotiation, peacekeeping and peacebuilding jobs [...]. Although the BNAP attributes responsibility for the organisation of both activities to the Ministry of Gender, the appointed implementing partners are the United Nations, international NGOs and CSOs. Therefore, in order to become mediators, women have to follow-up a series of trainings organised by the UN

\footnotetext{
72 Interview with Clarisse, 31 years old, combatant, in "Combattantes au Nord Kivu ».

73 MacKenzie, op.cit.

${ }^{74}$ Elise Barth, Peace as Disappointment: The Reintegration of Female Soldiers in Post-conflict Societies: $A$ Comparative Study from Africa (Oslo: PRIO, 2003); Megan MacKenzie, "Securitization and desecuritization: female soldiers and the reconstruction of women in post-conflict Sierra Leone", Security Studies, Vol. 18, No.2, (2009), p. 241-61; Helen Basini, "Gender mainstreaming unraveled: the case of DDR in Liberia", International Interactions, Vol. 39, No. 4 (2013), p. 535-57.

75 Interview with Louise, 20 years old, combatant, in « Combattantes du Nord Kivu ».
} 
and certain international NGOs together with CSOs, that enact the norms and rules to which they have to adhere in order to be good mediators. The result is a fast professionalization of a handful of women mediators who rapidly adapted and learnt the skills and knowledge provided during trainings. ${ }^{76}$ One of our interviewees explained that she followed one of these trainings when she worked with a local women organisation and that her perception of how things worked changed: "Before [receiving the training] I did not think that having women in public life could change the status of women in the country, but now I think it is true". ${ }^{77}$ By so doing, not only do the workshops co-op local knowledge, but they also control the subjectivities and orientations of those women mediators who will be given authority and legitimacy in the post-conflict period. ${ }^{78}$

The outcome of this can be seen now, as Burundi is drawn in a political crisis at the time of writing that started with the electoral process in 2015 and that included a failed attempt at a coup d'état in May. Following the declaration of a 3rd candidature by President Nkurunziza, which many saw as a violation of the Constitution that only validates 2 terms, but which was endorsed by the Constitutional Court of Burundi, the opposition parties boycotted the elections. Since President Nkurunziza won the ballot, murders and disappearances have characterised the current state of affairs. A new nation-wide network of 534 women mediators across all municipalities in Burundi, established by the UN in partnership with the Ministry of Interior and CSOs, has been used as dialogue initiators between government and protesters, between conflicting parties and "promote non-violence and dialogue, and counter rumours and exaggerated fears with verifiable information". ${ }^{79}$ The mediation project is supported by the UN Peacebuilding Fund and is titled "Promotion of women's role in peace consolidation" (project PBF/BDI/A-11). The project, managed by UNWOMEN, conveniently ran from December 2014 until March 2017, and it intended to support women mediators in rural communities in order to prevent conflicts from escalating. It also intended to increase

\footnotetext{
${ }^{76}$ Maria Martin de Almagro, « La professionnalisation des associations locales des femmes dans la reconstruction post-conflit au Burundi : une stratégie de survie ? ", in David Paternotte and Petra Meier (eds.), La professionnalisation des luttes pour l'égalité : enjeux théoriques et politiques (Louvain-laNeuve: Academia, 2017).

77 Interview with a former member of staff of a local civil society organisation, Bujumbura, Burundi, 12 June 2013.

${ }^{78}$ Norma Vázquez, "Motherhood and sexuality times of war: The case of women militants of the FMLN in El Salvador", Reproductive Health Matters, Vol. 5, No. 9 (1997), p. 139-146.

79 UN Peacebuilding Fund, Women Mediators Promote Peace in Burundi, (2016) and Radhika Coomaraswamy et al., op.cit.
} 
the role of women in regional and international dialogue fora ${ }^{80}$ Women mediators like Ms. Nyandwi "were chosen for their previous experience" with international projects in conflict prevention and resolution during the first years of peace after the end of the civil war and implementation of UNSCR1325, "and have been further trained by UN Women." $" 81$

A hierarchical divide is established through the discourse of women as mediators that first separate "brown" women experts from other troublesome or invisible "brown" women who have not been target of intervention and fabrication through the international training executed by local women elites, and cannot therefore mediate and be competent agents of societal transformation. This also resonates with Mohanty's analysis of development discourse on the "average third world woman" as "ignorant, poor, uneducated, tradition-bound, religious, domesticated, family-oriented, victimized, etc." 82 Trained by local women CSOs, the woman mediator becomes a subject created in superiority to the "brown women" victim of "brown men" on whose behalf she is speaking: "Victims of conflict trust us to solve their problems in an effective and respectful manner," said Ms. Nyandwi. ${ }^{83}$ What is more, this subject is conscious of the hierarchical divide and its possible negative impact for the community. She must take this ambiguity in her position into account when she acts, so she indicates that "our strategy is to build partnerships... to avoid the community thinking we are acting on our own. " 84 Secondly, it creates a divide between "brown men" as future perpetrators of violence and certain "brown women" with "white training" as mediators, as they "diffuse tensions, for example, by mediating between security forces and protesters, and advocate for the release of [male] demonstrators and political prisoners." 85

A second set of questions that arises from this tale concerns what is considered as "verifiable information" 86 , who has and provides this "verifiable information" to these women and whether these women's lives are not been put in very dangerous positions in the same way as women used in countering violent extremism strategies or

\footnotetext{
80 UN Peacebuilding Fund, Burundi Overview, (2016), available: $<$ http://www.unpbf.org/countries/burundi/> (accessed 9 January 2017).

${ }^{81}$ UN Peacebuilding Fund, Women Mediators Promote Peace in Burundi, (2016).

${ }^{82}$ Chandra Mohanty, "Under Western eyes: Feminist scholarship and colonial discourses". Feminist Review, Vol. 30 (1988), p. 61-88.

${ }^{83}$ UN Peacebuilding Fund, Women Mediators Promote Peace in Burundi, op. cit.

${ }^{84} \mathrm{lbid}$.

$85 \mathrm{lbid}$.

86 Ibid.
} 
counterterrorism strategies. ${ }^{87}$ The argument is that women are natural allies in fighting against war or violence, and Western decision makers believe that women's empowerment and participation in mediation is key to global security and stability. ${ }^{88}$ First, one does wonder whether this verifiable information is provided by UNWOMEN or the PBF or any other UN entity or whether thanks to training and previous expertise at working in mediation, these competent women know what constitutes verifiable information and what does not. Secondly, not only are we seeing a co-optation of certain rural women as mediators, but also a securitization of these women's lives in conflict zones as mediators of disputes in which their family and village are involved.

In Liberia, the Liberian Women's Initiative (LWI) led the women's movement for peace in the 1990s and played a key role as informal mediation between warring sides during the civil war. Their mediation capacities were such that one of their leaders, Ruth Sando Perry, was chosen to chair the Council of State during the transitional government, between September 1996 and July 1997. Liberia is used as the example of a success story by the international community, and the accent on the mediation capacities as part of the women's identity makes other women's experiences of war and post-conflict reconstruction shout out and invisible. The emphasis on the woman mediator is such that the LNAP proposes to include women in the revitalization of traditional nonaggression pacts, and one of the indicators to measure this inclusion is the "number of pacts revitalized and in use and number of competent women included". Even though there is no definition of what a competent woman is, one page afterwards the LNAP indicates that another priority area is the expansion and re-designing of "existing peace training curricula to develop and deliver a certificated peace-building training program for women at national, country, community and sub-regional levels in consultation with UL, WIPNET, WIPSEN, DRC and MARWOPNET". These are international NGOs and regional and national women's organisations founded and funded by international programs. As we will see in the next sub-section, the women leading these organisations are part of the highest social classes in their country and belong to a transnational elite of activists. As the leader of a grassroots women's organisations explained, rather than empowering women to define how they want to become mediators, powerful national

\footnotetext{
${ }^{87} \mathrm{Ni}$ Aoláin, op. cit.; Pratt, op. cit.

${ }^{88}$ Hillary Clinton, Remarks at the $10^{\text {th }}$ Anniversary of UNSCR1325 on Women, Peace and Security $(26$

October 2010), available: $<$ http://www.state.gov/secretary/rm/2010/2010/150010.htm $\geqslant$, (accessed 13 November 2016).
} 
and international actors develop workshops that determine what mediation is and who gets to be a mediator, conflating these with the ideas women mediators had in the first place: "We have been negotiating with husbands that do not want their wives anymore, husbands that drink and hit, all our lives. Now we have to wait for Thursday to arrive to go to the [Peace] Hut." 89 The competent "woman participant" as mediator is thus positioned in a particular subordinate location that is instrumentalized as a source of mediation or information, and while she is a source of authority amongst brown men and women, she must be taught on how to be a competent mediator first.

\section{The woman activist or the intersection between gender and class}

The woman activist represents local experiences of conflict and peace in the international arena and her discourse is used as evidence in international reports. ${ }^{90}$ As the woman mediator, she has also followed training to be competent, but it is of a different nature. Indeed, whereas being a mediator is a "local" and assumed to be "apolitical" job, ${ }^{91}$ the woman activist has a more international role. It is therefore an elite position. The woman activist speaks several languages, preferably English. While this is understandable for practical reasons, this often means that the woman has a particular background and socio-economic status, international friends and has probably benefited already from international experiences and travel. The competent activist is selected and produced by international NGOs to work on advocacy at international level. One of our interviewee explained how "several women, including myself, were selected by UNWOMEN to meet Burundian women from the diaspora in Tanzania and start creating transnational links." ${ }^{\prime 2}$ It is also through these meetings that a transnational elite of women activists is created. For instance, one activist in Liberia explained that "UNWOMEN had organised a workshop on gender last year in November, and they brought women activists from countries where there are UN

\footnotetext{
${ }^{89}$ Interview with a leader of a rural grassroots women organisation, Montserrado county, Liberia, 24 August 2013. The Peace Huts project is a UNWOMEN initiative that offers a physical space for rural women to gather and discuss issues from economic inequality to physical insecurity. For a longer discussion on the project and its consequences for rural women groups, please, see Petra Debusscher and Maria Martin de Almagro, "Post-conflict women movements in turmoil: the challenges of success in Liberia in the 2005 aftermath", Journal of Modern African Studies, Vol. 54, No. 2 (2016): 293-316.

90 Soumita Basu, "The Global South writes 1325 (too)", International Political Science Review, Vol. 37, No. 3 (2016), p. 363.

${ }^{91}$ Sue Brownill and Susan Halford, "Understanding Women's Involvement in Local Politics: How Useful is a Formal/Informal Dichotomy?”, Political Geography Quarterly, Vol. 9, N. 4 (1990),p 396-414.

92 Interview with a staff member of a national women's organisation, Bujumbura, Burundi, (12 June 2012).
} 
peacekeeping missions so that we could study the similarities and differences in the diversity of contexts. "93 There is a clear division between those activists that receive training and professionalise, and who feel they have the legitimacy and the authority to become leaders of the women's movement in their country, and those who act in an informal manner, without access to human or financial resources and who need to be protected by the first ones: "I want to give back to the local women what I have received from the international $N G O s . ", 94$

In this context of promotion of activist leadership, the LNAP proposes the creation of a Civil Society Monitoring Observatory, which will prepare a Shadow Report at the end of the four-year planned period. The LNAP includes a precise list of NGOs that could take part in the Observatory and references Community Based Organizations as essential partners and observers in the implementation process. However, although national NGOs are rendered visible by including their name on the NAP, community based organisations are simply acknowledged, given a secondary, more silenced role. The LNAP grid of intelligibility makes it a hard task to see troublesome and invisible women activists. In Liberia, there are those women who were never part of CSOs, but who form small groups of women farmers or dressmakers so as to join forces to share profits and challenge established patriarchal rules of male breadwinner and female nurturer. In many occasions, these are loose organisations with a self-appointed leader around which women gather and organise. Sometimes, these women are ex-combatants or previously displaced people. However, to the question of whether there are women ex-combatants in their organisation, the Secretary General of a Liberian national women's organisation explained that "we don't work with them because we represent the interests of women as a collective." "95 She then proceeds to acknowledge that "at the highest activism level, there are very few of us, and in the majority of cases we act as gatekeepers who do not let other women talk. The vast majority of us do not help other women succeed." 96

\footnotetext{
93 Interview with the Secretary General of a national women's organisation, Monrovia, Liberia, (3 September 2013).

94 Interview with a programs officer of a national women's organisation, Bujumbura, Burundi, (15 June 2012).

95 Interview with the Secretary General of a national women's organisation, Monrovia, Liberia, (6 September 2013).

96 Ibidem, cited in Debusscher and Martin de Almagro, op. cit.
} 
Moreover, grassroots women organisations see elite activists as not being very different from female politicians and it is very common to find elite women activists in government and back to activism. This is very troublesome, they argue, because they would advocate for are issues that "only concern women of their class.${ }^{97}$ For instance, since 2009, the Women's Legislative Caucus, a group of women parliamentarians from all party lines, together with UNWOMEN, have been advocating for an "Affirmative Action Bill" with the aim of establishing seven "Special Constituencies" in the House of Representatives amongst which five seats would be reserved for women, one for youth and one for the disabled. The passing of the law in August 2016 was seen as a milestone achievement by UNWOMEN and women's organisations, but it came after years of rejection. This was not only due to a sexist male dominated legislature, but also to the lack of support from civil society after a good amount of women's groups considered the process as elite-driven and lacking broader consultation. ${ }^{98}$ Grassroots women, instead, lamented the lack of engagement of the leaders of the women's movements and the international community on a Local Government Act that would make it easier for women to gain access to political seats at local and regional level. ${ }^{99}$ However, either the PBF or UNWOMEN in Liberia have partnered with women's organisation for this campaign.

In Burundi, the breach between the urban and educated female elite of women activists, supported by international actors, and rural women activists is also very visible. UNSCR1325 and the WPSA have been used by the main women's organisations in Burundi as a tool for advocating for women's right to inherit land. Despite women's activism, the issue of women's land inheritance was let aside and never voted at the Parliament. After a presidential intervention on July 28 2011, Pierre Nkurunziza, the President of the Republic, demanded to halt all advocacy activity on the issue. Grassroots women associations were to a great extent against advocating for the right to inherit, and argued that there was no need to divide land even more when they could always use the land of their husbands. At this point, it is important to acknowledge a caveat: this breach between classes was used as well as an argument to undermine women groups' credibility by the opponents of the right to inherit. "The [majority] has

\footnotetext{
${ }^{97}$ Interview with leader of a rural grassroots women's organisation, Monrovia, Liberia, (5 September 2013).

${ }^{98}$ Interview with a representative of an international donor organisation, Monrovia, Liberia, (20 August 2013).

${ }^{99}$ Martin de Almagro, « Politicized Discourses », op. cit.
} 
the "opinion" that fighting for gender equality in inheritance law is an issue of educated women who, erroneously, try to influence rural women." 100 Interviewees clearly showed this tension and disconnect exacerbated by the professionalization and socio-economic benefits of a certain feminine elite and a certain resistance to what they perceived as dangerous to their customary practices and ancestral land. ${ }^{101}$ In sum, women leaders of the inherit land campaign in Burundi in the same way as the campaigners for the Affirmative Action Bill in Liberia have missed the opportunity to participate as women for all the women.

\section{Conclusion}

Through a heuristic device, this article has examined how the subject position(s) of the competent, troublesome and invisible woman participant are constructed through a hierarchical ordering of social categories. Confirming the findings of other feminist postcolonial and poststructuralist scholarship on security and peacebuilding, this article shows that WPS is part of a liberal peacebuilding framework that is racialized, patriarchal, classist, heteronormative and Western-centric at its core. One cannot forget that these fixations are built upon a certain distribution of power and therefore restrict the opportunities available to act upon a given agenda. In all three cases the interaction between the local and the international through the activities proposed by the NAPs create hierarchical and binary divisions that craft the figure of the woman participant and influence the policies, programs and discourses concerning women, peace and security in post-conflict contexts. Even if only momentarily, subjects can still subvert and trouble the positioning that has been assigned to them. As Basu indicated, "there will always be a hegemonic WPS narrative, articulated in dominant readings of UNSCR 1325 , but it exists within a much larger discourse on WPS."102

These findings confirm that although the WPSA is a strategic tool for gender mainstreaming and gender equality in post-conflict contexts, there is a need to create new narratives and provide new meanings to participation in post-conflict reconstruction that challenge the sexual, class, and racial boundaries of the subjectpositions assigned to womenparticipants. The effort to include women as participants

\footnotetext{
${ }^{100}$ Marie Christine Ntagwirumugara, Etude sur les causes profondes de l'opposition a la loi sur les successions sensibles aux inégalités de genre (Bujumbura: CARE International et CARE Autriche, 2011). 101 Interview with a rural woman activist in Cibitoke, Burundi, (13 June 2013).

102 Basu, op.cit., p. 371.
} 
will do little to address the experiences of a diversity of women until the ramifications of racial, class and sexuality stratification among women are acknowledged. Such a project of new meaning-making could be translated into research that looks at how the different representations overlap. For example, future research could look at how women mediators are racialized but also sexualised, and how women ex-combatants are marginalised by the elite of women activists, or how women mediators are trained by these same women activists belonging to urban, elite CSOs.

Decolonizing WPS, therefore, involves the formulation of tools or strategies that do not only condemn dichotomous hierarchies, but that also open spaces for troubled and silenced representations to show their full potential, offering a holistic understanding that represents much more clearly the everyday needs and experiences of those WPS regulates. In policy terms, this could be translated into an avoidance of qualifying gender mainstreaming policies into a success or a failure, but instead in an acknowledgement on how these processes of change are being played out in context and the consequences these have on those individuals the policy was designed to help. It also involves thinking in an intersectional way in order to construct a truly transformative project in which women's agency in conflict zones and in particular moments in history can manifest itself in myriad ways.

\section{Acknowledgments}

I presented the first draft of this article at the Global Society Workshop on Gender and Security at the University of Kent in January 2017. I would like to thank the organisers and the participants of the workshop for providing very constructive criticism and encouraging me to continue working on this article. I presented a second draft of this article at the International Studies Association in Baltimore in February 2017 and at the European Conference on Politics and Gender at the Université de Lausanne in June 2017. I thank the participants of both panels for their insights and comments. Also, I am indebted to the two anonymous reviewers and the editors of this journal for very fruitful feedback which has greatly shaped this article.

\section{Notes on contributor}


Maria Martin de Almagro is a Marie Curie postdoctoral researcher at the Department of Politics and International Studies of the University of Cambridge and Assistant Professor in International Affairs at Vesalius College (VUB). Prior, she was a postdoctoral researcher at the Université libre de Bruxelles. Her research focuses on gender politics, international security governance and the micro-dynamics of war-topeace transitions.

Contact email: mm2256@cam.ac.uk 